\title{
Christos Yannaras's Conception of State, Society and Politics and the Greek Apophatic Tradition
}

\author{
Miroljub Gligorić \\ Collaborator of the Competence Centre for Intercultural, Interreligious and \\ Interconfessional Teaching, University College of Teacher Education Vienna/ \\ Krems, Vienna, Austria \\ phileirin@yahoo.co.uk \\ miroljub.gligoric@kphvie.ac.at
}

\begin{abstract}
The article demonstrates a concept of state, society and politics coined by contemporary Greek religious philosopher Christos Yannaras. The concept derives from two sources: on the one hand from the criticism of the modern cataphatic forms of state and society and on the other hand from the apophatic character of the Greek polis. With this creative critical synthesis, based on the apophatic attitude, Yannaras produces a conception of a new polity, contributing to the liberation of the human subject from various aspects of alienation in the cataphatic systems.
\end{abstract}

\section{Keywords}

apophaticism - polis - democracy - logos - society

\section{Introduction}

In some of his works, the contemporary Greek philosopher Christos Yannaras (1935) offers an inspiring and noteworthy vision of state, society and politics based on the political culture of the ancient Greek polis. This conception represents a theory which originates both from the Greek theological and philosophical apophatic tradition i.e. from the apophatic mode of the usage of recta 
ratio (op $\left.0 \dot{\partial} \varsigma \lambda \hat{o}^{\prime} \gamma \varsigma\right)^{1}$ as well as from Yannaras's interpretation of the mode of life of ancient Greeks. The following article focuses on Yannaras's lesser known conception of state, society and politics and shows its philosophical and theological apophatic background. It addresses some basic concepts of Yannaras's approach to this subject, without delving too deeply into all its direct and indirect implications.

Significant for understanding the conception of Yannaras is the difference between the cataphatic and apophatic logic. Yannaras shows how these two approaches are used both in theological and philosophical theoretical discourses and how they actually generate two different stances toward reality. Moreover, he stresses that they also create two different conceptions of state, society and politics. ${ }^{2}$

\section{$2 \quad$ The Cataphatic Paradigm}

The cataphatic perspective represents a rational approach to reality. It is the individual reason of the human subject, which due to its cognitive capacities cognizes the reality, defines it and expresses the cognition in a form of objective and positive knowledge. This cognitional method offers to the cognizer a certain and reliable knowledge but, at the same time, subordinates him to the predominance of logical argumentation and, especially nowadays, to autonomized systems of different scientific disciplines. What is more, the cataphatic methodology has a strong impact on the organization of human life according to criteria of rationality and objectivity. In that sense, the well-known premodern and modern governmental and societal forms of organization (e.g. tyranny, monarchy, theocracy and types of republics as well as capitalism, socialism and communism) are created according to rational schemes and use rationally structured mechanisms and modes of operation, in order to work as functionally and efficiently organized political system. Comparing these models, Yannaras concludes that they do not have substantially different logical

1 Yannaras stresses that in the Greek antiquity, the concept of op 0 os $\lambda$ ó $\gamma \circ \varsigma$ (recta ratio) referred mainly to the practice of correct formulation, expression and discernment, whereas the term ratio in its later and contemporary usage signifies primarily the rational capacity of the individual (facultas rationis). Also, he points out that in the Ancient and Medieval Greek the Latin concept of rationalism was unknown. The absence of the term signalizes a different usage of rationality in the Greek culture. Cf. Yannaras, Orthos logos kai koinōnikē praktikē

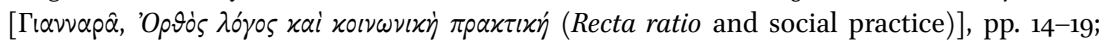
Gligorić, Person-Logos-Sein, pp. 233-25o.

2 Cf. Yannaras, Orthos logos kai koinōnikē praktikē, pp. 181-187, 196-199. 
background, but diverge from each other only as different ideological outlooks of the same cataphatic paradigm. ${ }^{3}$

\section{Basic Aspects of Theological and Philosophical Apophatism ${ }^{4}$}

Yannaras argues that in the fundamental sense the human being cannot be defined as self-conscious, thinking subject, but rather as person..$^{5}$ According to his reasoning, the cognition of reality, in the way of the fundamental ecstatic and personal relation towards beings, is inseparable from the mode of existence. The latter means that the cognizing relation towards beings is first and foremost pre-rational. ${ }^{6}$ Besides the reception and correction of Heidegger's criticism of the captivity of the Western thought in the rational subjectivism, ${ }^{7}$ Yannaras shows on the basis of Marx's and Lacan's analyses that human being exists first and foremost as relation and that the relation causes the prerational, fundamental mode of cognition that precedes the cognition of the object performed by a subject. ${ }^{8}$

Yannaras's other main source for the concepts of personhood and relationality is Orthodox Triadology - especially the teaching on the Trinity of the Cappadocian Fathers (4th century). ${ }^{9}$ This theological teaching clarifies the Christian faith in the Triune God as well as the use of certain ontological terms

3 Cf. Yannaras, Orthos logos kai koinōnikē praktikē, pp. 258-262, 324-332; Yannaras, The Schism in Philosophy, pp. 104, 141-142; Yannaras, To pragmatiko kai to phantasiōdes stēn politikē oiko-

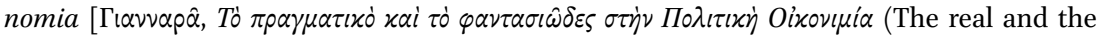
imaginary in the political economy)], pp. 129-147.

4 The apophatism is primarily known as a (negative) theological method of cognition. Yannaras identifies it already in the Greek philosophical tradition, especially in Heraclitus', Democritus', Plato's and Aristotle's texts. As for the Greek theological apophatism, cf. Yannaras, On the Absence and Unknowability of God, pp. 73-114; as for the apophatism in the Greek philosophy, cf. Yannaras, The Schism in Philosophy, pp. 43-46, 72-79; Yannaras, Orthos logos kai koinōnikē praktikē, pp. 183-192, 199-210.

5 Cf. Yannaras, Person and Eros, pp. 5-8.

6 Cf. Yannaras, Person and Eros, p. 19 et seq.

7 Cf. Yannaras, Person and Eros, pp. 8-15, 17-18.

8 Cf. Yannaras, Orthos logos kai koinōnikē praktikē, pp. 99-169; Skliris, Christos Yannaras' Political Ontology, pp. 28-34; Gligorić, Person-Logos-Sein, pp. 143-179.

9 It should be mentioned that also the concept of eros, in its primarily Patristic connotation (Pseudo-Dionysius the Areopagite, Maximus the Confessor), plays for Yannaras a crucial role in defining personhood and relationality. Within the frame of this topic, it cannot be further examined. Cf. Yannaras, Person and Eros, pp. 142-145. 
to express this faith..$^{10}$ Correspondingly, the Father, as the source and the principle of the Godhead, being absolutely free begets the Son and makes the Holy Spirit proceed from him. Yannaras stresses that the "Father" and the "Son" and the "Holy Spirit" are not individual, but relational denotations. Also, "begetting", "procession", "fatherhood" and "sonship" refer to relations in the course of which the hypostases of the Son and of the Holy Spirit as well as their identities (otherness) are constituted. The constituting will, love and self-transcendence of the Father, which gives existence to the personal hypostases of the Son and of the Spirit, and the "reverse" loving relation of the Son and of the Holy Spirit to their source and ontological principle constitute the unity of the Godhead. Therefore, for the Christian East, God is one not because he is one transcendent and supernatural essence, but because he is the free and loving person of the Father, on whom the unity of the three hypostases is based. Consequently, the definition "God is love" ( 1 John 4:8) actually refers to these free and loving divine relations of otherness and community and not to the natural sentiment of love. Also, the Incarnation indicates the relationality of the three divine hypostases. ${ }^{11}$ Likewise, in the loving relations of the divine hypostases, being, existence, otherness, cognition and community are interwoven and compose the nucleus of the existence-oriented and integral Eastern Christian apophatic attitude, which represents a gnoseological stance that is based on the reality of the person i.e. on its existential categories of freedom and otherness. ${ }^{12}$

Yannaras points out that the way humans are created i.e. as "image and likeness of God" (Gen 1:26-27) does not mean to objectify any capacity of the human nature (e.g. animal rationale), but rather refers to the mode of existence that is similar to its divine prototype. According to this perspective, humans come into being through relationship - they relate to surroundings, live with the others and also relate to God; some of them leave this world in personal relationship with God as the source of their existence and their counterpart. In that context, Yannaras implies the teaching of St. Maximus the Confessor on man as "microcosm" and "mediator" i.e. as a being who unites in himself in a personal way the psychophysical elements of the cosmos and mediates between immanent and transcendent reality, which actually means that he represents the very centre of the cosmic relations. ${ }^{13}$

10 Cf. Yannaras, Person and Eros, pp. 15-17, 251-255; Yannaras, The Schism in Philosophy, pp. 194-210; Zizioulas, Being as Communion, pp. 27-41.

11 Cf. Yannaras, Christos, Relational Ontology, pp. 49-55, 58.

12 Cf. Yannaras, Christos, On the Absence and Unknowability of God, p. 72.

13 Cf. Yannaras, Christos, Elements of Faith, T\&T Clark, Edinburgh 1991, pp. 46-48, 53-59, 65-74; Yannaras, To pragmatiko kai to phantasiōdes stēn politikè oikonomia, p. 140 et seq. 
These briefly summarized triadological and anthropological explanations of Yannaras bring to the fore that personhood is primarily characterized by relations, which manifest uniqueness and originality. Whereas the well-known definitions of human being as animal rationale (Aristotle/Thomas Aquinas) as well as persona est naturae rationalis individua substantia (Boethius) focus on general characteristics of human being, the otherness defines the quality of uniqueness of every person. In the case of human being, the latter comes to expression in his personal name, while the otherness in God is manifested by the three unique transcendent relations of the three divine persons (fatherhood, sonship, procession), which give them "names". In the language of the Church Fathers the originality of every human person is defined as the mode

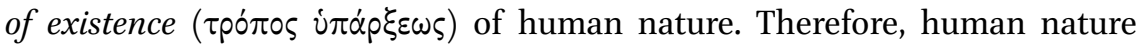
cannot be captured only by a universal categorization of a concrete individual human being, but actually exists only in the mode of unrepeatable and unique persons. ${ }^{14}$

Depending on the approach by which the human being is conceived and defined, the mode of cognition is determined as well. Concerning this point, Yannaras combines analyses of Heidegger and St. Maximus the Confessor in order to explain the mode of cognition before any objectivization and positivization of knowledge. According to this synthesis, human being stands out from his essence and in the ec-stasy encounters logoi of beings/things cognizing them through his own logos. The human logos, however, encompasses not only reason, but the whole of the cognitional capacities of human nature. In that sense, beings/things direct a "call" and the logos of the human being responds to this call in a dia-logical way. This pre-rational encounter, which is ultimately based on the initial cognitive capacity of the human logos, results in the "coordination" of the logoi producing pre-semantic and integral cognition. In that sense, the logos of beings reveals the essence of beings, but it does not "exhaust" it; in its totality, the essence remains unreachable for cognition. This way of cognition of personal and dia-logical relation is experiential and a possibility i.e. it is liberated from the compelling character of logic. In that sense, it extracts beings from impersonal neutrality and overcomes their utilization. If beings are transferred from the reifying context into the personal, personhood is simultaneously "saved"; it is on the one hand "saved" from the irrationality, and on the other hand from the impersonal character of rationality, which cognizes all the objects on the same intellectual basis. Moreover, every relation of the human logos with the logoi of beings is unrepeated, which substantially

14 Cf. Yannaras, Christos, Elements of Faith, 26-33; Gligorić, Person-Logos-Sein, pp. 68-76. 
impacts the mode of cognition, which does not lack clarity, but rather manifests uniqueness. ${ }^{15}$

In order to clarify cognition at a fundamental level, Yannaras implies the teaching of the Greek Church Fathers on the distinction between essence and energies, which represents a well-established doctrine in the Eastern Christian apophatic theology. ${ }^{16}$ This teaching was eventually formulated after heated debates in the 14th century Byzantine Empire on the question whether and how it is possible to experience the community with God already in this life. Correspondingly, the cognition of God is possible as the encounter of the human and the divine person, which both communicate with each other not by their essences, but over the personal energies of their nature. The cognition based on such an encounter not only overcomes positive knowledge, but also the vague "mysticism of essence" as well as phenomenological modes of cognition. It rather "happens" as an existential and experiential encounter of the human and the divine persons. ${ }^{17}$ This particular "level of cognition" is missing in the conventional understanding of knowledge. In order to respond to the requirements of the theological apophatic process, it is necessary to reunite the capacities of human nature, such as "the intellect and the heart, logos and action, ethos and being" and to integrate them in a universal (catholic) existential and experiential approach to the divine person of God, because both his person and human persons also reveal themselves in a universal (catholic) way i.e. beyond the separating and dividing function of reason. ${ }^{18}$

In this cognitional process, the logos does not "exhaust" the essence as it would be the case in the context of ontic, individual, rational cognition, which is situated in the coincidence of the concept with the object conceived. In the personal i.e. apophatic mode of cognition, however, definitions and notions are only considered "symbols" which signify the "object" of cognition on the basis of the logos of nature. This "symbolic" character of language is particularly evident if the correspondence of the logoi has a deep personal character such as in a love song or in prayer. ${ }^{19}$ Yannaras points out that especially theological apophatism not only combines cataphatic and apophatic expressions, but also uses "synthetic" expressions in order to "enlarge our capacities

\footnotetext{
15 Cf. Yannaras, Person and Eros, pp. 34-42, 168, 249-251; Yannaras, The Schism in Philosophy, pp. 44,69 .

16 Cf. Yannaras, Person and Eros, pp. 57-59, 63-64.

17 Cf. Yannaras, Person and Eros, pp. 33, 66-70, 171, 176-184.

18 Cf. Yannaras, He hapologêtikè sta horia tès orthodoxou theologias (Apologetics in the context of Orthodox theology), p. 13, in: Petrà, Christos Yannaras, p. 30 et seq.; Gligorić, Person-Logos-Sein, pp. 76-80.

19 Cf. Yannaras, Person and Eros, pp. 66-68, 167-172.
} 
for knowledge, beyond the intellect, into a catholicity of experience", which means the dynamical and universal reality of cognition in person. ${ }^{20}$

Evidently, the apophatic attitude of the Eastern Church Fathers is not based on the cognitional method of negation but, as its core, it has the reality of the personhood. Yannaras determines the person as relationality, otherness and freedom. Whereas the ratio subordinates all the objects of cognition to common rational categories and in that way dominates over them irrespectively of whether they are God, human beings or the world, the apophatic attitude identifies otherness in the "object" of cognition and in that way enables acknowledgement of the dignity of beings; it also stresses the substantial role of the inter-subjective "con-sensus" of the community for the verification of the truth. What is more, the apophatic attitude also includes existential factors as essential preconditions in the cognitional process. The inclusion of principles such as community, freedom, otherness, alienation, sense, ethics and ontology, interpreted apophatically, does not aim to relativize the logical character and structure of knowledge, but, on the contrary, it gives to the rationality a quality of deeper sense. ${ }^{21}$ Yannaras discovers the deeper sense in the apophatic features of the organization and the way of life in the ancient Greek polis. Likewise, he argues that despite a number of apparent similarities with our modern theoretical and practical political perceptions, based on cataphatic logic, the polis culture differed essentially from them. ${ }^{22}$ Hence, he transfers the idea of the apophatic mode of organization and life of the polis into a vision of a future governance and societal form.

In his interpretation of the polis, Yannaras describes a former, nowadays nonexistent, mode of civic life that was practiced in Greek city-states. ${ }^{23}$ Yannaras admits that not all the Greek poleis, and not in all times, shared this specific mode, but he asserts that the fact of this once performed cultural "miracle" counts more than its quantitative duration. ${ }^{24}$

\footnotetext{
20 Cf. Yannaras, On the Absence and Unknowability of God, pp. 69-72.

21 Cf. Yannaras, Orthos logos kai koinōnikē praktikē, pp. 185-187.

22 Cf. Yannaras, Orthos logos kai koinōnikē praktikē, pp. 193-196; Yannaras, Hexi philosophi-

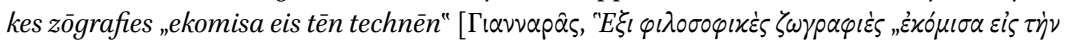
T⿱㇒́ $\chi \nu \eta \nu^{\prime \prime}$ (Six philosophical sketches "I have brought to art")], pp. 40-44.

23 Cf. Yannaras, Orthos logos kai koinōnikē praktikē, pp. 197-198.

24 Cf. Yannaras, Hexi philosophikes zōgrafies „ekomisa eis tēn technēn", p. 40.
} 
The main characteristic of this specific culture $(\pi \circ \lambda i \tau i \sigma \mu o ́ s)$ was the active participation ( $\left.\mu \varepsilon \tau \circ \times \eta^{\prime}\right)$ of all the citizens $(\pi \circ \lambda i \tau \varepsilon \varsigma)$ in the life of the polis. This participation was conceived as neither an individual right nor an obligation, but as a natural expression of responsibility of citizens for their city. Consequently, the citizen was not only an individual living in an urban area who is formally entitled to citizenship and specific rights, but being a citizen implied an essential willingness for being engaged in the common affairs of the polis-community in the sense that this participation builds up the polis. It is, actually, this very responsibility of all for coexistence and the common good that constituted the polis and gave a specific cultivated and cultural shape $(\pi \circ \lambda i \tau i \sigma \mu o ́ \varsigma)$ to the life of the citizens of the polis $(\pi \circ \lambda i \tau \varepsilon \varsigma){ }^{25}$

In Greek Antiquity, the precondition for the status of a polis was not quantitatively determined: the city did not mean a larger urban area, as is the case nowadays, nor was the common life of the polis-community a flock-like or a necessity-like mode of existence with additional cultural superstructure (Überbau). The polis was principally a community of citizens gathered around common matters and coming to a decision about them. This common struggle ( oเvò $\ddot{\alpha} \theta \lambda \eta \mu \alpha$ ) was not based on utilitarian principles, even though existential necessities were not neglected, but the priority was rather a common effort of searching the truth in diverse questions and problems, and this struggle for a life according to the truth was an essential factor which gave the Greek polis culture its specific profile. ${ }^{26}$ The latter functioned in its essence as an activity of the logos i.e. as the partaking of all the citizens in the "common logos", which was also considered the governing principle of unity and harmony in the cosmos as well as in the urban community. In putting oneself at the disposal of the community, solving a common problem and participating in common affairs, the citizen took part in the universal mode of reality. This mode was conceived as the cosmic and urban harmony of beings i.e. as the complementarity of the logoi. The synchronization of their modi i.e. of the ways the beings act and relate to each other created a perception of the world as the "everlasting" order. ${ }^{27}$

Consequently, the concept of the "logos-tropos" of beings generates a specific understanding of truth: it transfers the truth from the exclusively rational, epistemic level to the ontological, existential and communal level. In that

25 Cf. Yannaras, Orthos logos kai koinōnikē praktikē, pp. 193-196, 198, 202; Yannaras, Hexi philosophikes zōgrafies „ekomisa eis tēn technēn", pp. 36-40.

26 Cf. Yannaras, Orthos logos kai koinōnikē praktikē, p. 202; Yannaras, Hexi philosophikes zōgrafies „ekomisa eis tēn technēn", pp. 36-40.

27 Cf. Yannaras, Hexi philosophikes zōgrafies „ekomisa eis tēn technēn", p. 237. 
sense, the truth (of beings) was not only considered an objectively ascertained result of rational cognition, but also a vivid manifestation and revelation of the "logos-tropos" of beings, i.e. of the way the beings are and relate to each other as well as to the cognizer. Therefore, the truth was not understood as a confirmed fact or phenomenon, but it appeared from a broader context of the physical, spiritual and communal harmony of the cosmos, which the participation of the citizens in the "common logos" tried to converge with as well as to realize it in their urban area. ${ }^{28}$

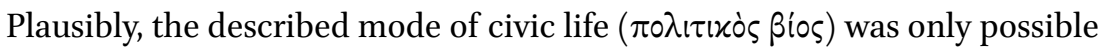
as democracy. It represented a special form of democratic culture, which substantially differed from today's cataphatic models of democracy. According to Yannaras, the main difference lies for sure in the apophatic way of the verification of knowledge i.e. in a particular conception of truth, which eventually impacts the way of thinking and consequently the way of organizing and ordering human life. Furthermore, the polis-democracy was characterized by the real and concrete rule of the people incorporated in the permanent opportunity for all citizens to shape the life of the city-state. Likewise, the democratic practice in the polis tried to imitate the harmonious order of the cosmos, which for the modern types of democracy is not a relevant feature. Also, Yannaras mentions a radically different form of practicing politics in the Greek democracy, which actually resembled a "creative participation in the realization of the authentic mode of existence", "skillfulness", an "art" or "virtue", so that the aim of politics in the polis was not an instrumental handling of power, but much more a struggle for a truthful i.e. an authentic way of life incorporated in the "common logos". As such, the polis-democracy was firstly a "spiritual" space with a special mode of living and a special way of perceiving the world as well as an urban entity with a specific common ethos. ${ }^{29}$

\section{5}

The Polis and the Early Church

According to Yannaras, the mode of life, the specific search for the truth and the ethos as well as the organizational form of the ancient polis-democracy met with the way of life and self-understanding of the early Christian communities

28 Cf. Yannaras, The Schism in Philosophy, 7-9, 43-46, 59-64; Yannaras, Orthos logos kai koinōnikē praktikēe, 188-192; Yannaras, Hexi philosophikes zōgrafies „ekomisa eis tēn technēn", pp. 21-28.

29 Cf. Yannaras, Orthos logos kai koinōnikē praktikē, pp. 192-199; Yannaras, Hexi philosophikes zōgrafies „ekomisa eis tèn technēn", pp. 36-40, 237-238. 
(Churches) of the Hellenized Roman Empire. The encounter of the similar cognitional and communal principles and practices mentioned above was an event of historical importance, so that the "ecclesia of the demos" could survive within the "ecclesia of the brethren" i.e. the "ecclesia of the faithful". Also, the genuine democratic spirit as the "struggle" $(\alpha \theta \lambda \eta \mu \alpha)$ for the authentic way of life within the community could find its continuation. According to Yannaras, the ecclesial community was the successor of the polis, but at the same time it manifested some differences from the prototype. ${ }^{30} \mathrm{He}$ even mentions that the image of the Church is the city (polis) of the New Jerusalem (Rev 21:2), which is "an icon of the Trinity, a communion of persons and city of saints, an organic unity of the body of the faithful [...]."31

The Eucharist and the whole life of the community did not only have the priority over private matters, but they were based on the living example of the Trinitarian life. Whereas in the polis the citizen had to obey the cosmic order, which was considered "everlasting", this was not required in the "ecclesia of the faithful". It did not search for an impersonal but for a personal form of immortality. This personal form was represented in the person of Jesus Christ to whom the faithful related in the Eucharist and afterwards. Due to the fact that free decision for baptism was indispensable, and corresponding to the baptismal theologies of the "new birth" (Rom 6:1-14) and the "freedom in Christ" (Gal 5:1), the freedom of the person emerged as the ontological principle. Actually, the conception of personhood emerged from the baptismal theology and practice. Correspondingly, the baptized was considered a liberated human with a new name. The latter grants dignity to the human life and represents the main difference between the communities of the polis and the Church. Also, the search for proper doctrinal definitions was performed in a dynamic and conciliar way i.e. according to the "common logos" of the community which manifests a substantial difference to ideology. In accordance with the Pauline theology of the gifts ( $\chi \alpha$ pi $\sigma \mu \alpha \tau \alpha)$ (1 Cor 12-14), the contribution to the life of the community was neither considered an obligation nor a right, but a special dignity regardless of the hierarchical level. The "ecclesia of the brethren" was also a community which tolerated existential failure and enabled a new beginning. These theses will be evident in the presentation of the apophatic vision of governance which is a fruit of Yannaras's creative thinking. ${ }^{32}$

30 Cf. Yannaras, Orthos logos kai koinōnikē praktikē, pp. 193-196; Yannaras, Hexi philosophikes zōgrafies „ekomisa eis tēn technēn", pp. 44-48, 231.

31 Cf. Yannaras, A Note on Political Theology, p. 151.

32 Cf. Yannaras, Hexi philosophikes zōgrafies „ekomisa eis tēn technēn", pp. 36-37, 46-48, 264-266; Yannaras, The Freedom of Morality, 81-83, 139-142, 219-223; Mitralexis, On the early development of Christos Yannaras's political theology, pp. 112-115; Yannaras, Kephalaia 
Based on his argument that the concept of rationality essentially impacts the organization of human life - and therefore the concepts of state and society -, Yannaras develops a vision of a future polity which is influenced by his interpretation of the apophatic character of the Greek polis. Predominantly, he presents only crucial ideas of the conception that could contribute to its establishment and general organization. However, he leaves particulars of their possible implementation to the dynamics of engagement and relations of the citizens.

In this regard, Yannaras argues for the establishment of small and relatively autonomous entities (communities), because only they could effectively enable the active participation of all citizens in governance, which is a substantial presupposition of liberation of the subject i.e. of freedom. He does not precisely determine the form and the settlement size of these self-governing communities and admits that requirements for such a radical reorganization of governance are not always met. The prerequisite for subsistence of the entities should be their ability to produce or acquire enough resources to meet the needs of their citizens. As for organization, some of the citizens should be assigned diverse responsibilities and they should take care of the execution of the "people's will". The assignments should be made in the spirit of democratic consent and in accordance with the capacities of the assigned, in order to make a proper contribution to the community. ${ }^{33}$ By no means does Yannaras neglect the role of the central government. In comparison to its cataphatic understanding, which deals with the efficient synchronization of the central and local government levels, the apophatic perspective perceives the central administration as a supervisor of the needs of the local autonomous entities. Its role should be to provide them with any assistance they need. The central administration should intervene only if it is necessary and the intervention should take place only if it does not violate the self-governing principle of the communities. ${ }^{34}$

In order to achieve the apophatic change, Yannaras does not even exclude revolution as a means of creating preconditions for the transformation of the society. Nevertheless, revolution is conceived to be the "last possibility" and should emerge from the fundamental readiness of the society for essential

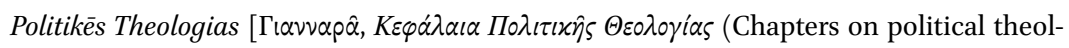
ogy)], p. 62.

33 Cf. Yannaras, Orthos logos kai koinōnikē praktikē, pp. 285-287.

34 Cf. Yannaras, Orthos logos kai koinōnikē praktikē, pp. 291-293. 
reformation of the relations that constitute it. Yannaras does not understand revolution in its usual (cataphatic) sense i.e. as a violent method of implementation of a priori formulated values or as an objective, collective claim, which results in acquisition of individual and collective freedom - although defined as "subjective possession and objective possibility". In that sense, the revolution is not conceived to have the ordinary character of merely gaining power and eliminating enemies, because this results, as historical experience shows, inevitably in establishing a new class of potentates, which, as the previous one, hinders once started reform processes and ends in encrustation of institutions, functions and initiatives. ${ }^{35}$

In the apophatic perspective, revolution could be primarily defined as a process of a profound and constant liberation of the subject. The latter should happen in the context of the revolution of relations within the society. This presumes a previous fundamental transformation of collective demands i.e. the transition from the "community of necessity" (

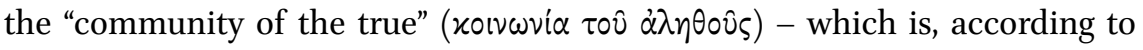
Yannaras, the event that once came about in the ancient Greek polis. Namely, the revolution would not lose its dynamics after revolutionaries gain power if this transition had already happened, but would actually manifest itself as a permanent demand for continuous improvement and development of relationships of the citizens. This implies a constant and extensive readiness and cooperativeness for changing the structures and reforming the relations of the agents. Such a process would involve diverse activities in many fields, so that Yannaras defines it as a universal phenomenon i.e. as an "eruption of fantasy and creativity" or as a "creative unpredictability". That means that the autonomous entity should evolve to an area of freedom as well as to a primarily "spiritual" space consisting of citizens who possess a high-leveled ethos of cultivated relations, responsibility and creativity. According to Yannaras, previous revolutions failed because they were rooted in the cataphatic patterns: they strived for transformation of structures of existing systems, but they did not overcome the "community of necessity" - they lacked, therefore, an essential awareness of far-reaching improvements in the field of human relationships, community, freedom and otherness. In other words, they neglected the ontological perspective. ${ }^{36}$

In the context of the reformed relations within the society, Yannaras offers a particular interpretation of labor and production. They are neither

35 Cf. Yannaras, Orthos logos kai koinōnikē praktikē, pp. 287-288.

36 Cf. Yannaras, Orthos logos kai koinōnikē praktikē, p. 288 et seq.; Yannaras, Hexi philosophikes zōgrafies „ekomisa eis tēn technēn", pp. 17-20; Yannaras, Against Religion, p. 86. 
conceived as a mere mechanical producing activity nor merely as significant prerequisites of subsistence of the autonomous entities, but rather as essential dimensions of being human - which Yannaras expresses in compliance with Marx. Depending on the fact whether labor and production represent plight, exploitation and finally existential senselessness, Marx speaks of "alienation of labor". ${ }^{37}$ Using the analyses of Marx for defining the nature of labor in the apophatic perspective, Yannaras points out that the primary objective of labor, production and practice does not consist in their instrumentalization for acquiring material or intellectual goods, positions, power or comfortable life, but labor should express the human being in its otherness, authenticity and freedom. Therefore, in the apophatic perspective, it is not limited to the means of existential survival, but it acquires a higher sense i.e. it manifests primarily its ontological and ethical character. This indicates that labor, by its dynamics of relations within the local autonomous entity, serves to the re-constitution of community, to acknowledgement of otherness of individuals and to obtaining freedom. Otherwise, instrumentalized for objectified and utilitarian purposes, being a static activity, labor becomes a fact of alienation of man from himself, nature and the world, as well as from fellow humans. ${ }^{38}$

Yannaras argues that the alienation of labor in the process of production cannot be overcome by a merely formal change of conditions of production such as: decentralization, greater participation of workers, applying the controlling mechanisms by workers themselves and even by abolition of private ownership etc.; 39 neither can it be overcome by political educational programs and promotion of particular moral values. All the exterior, cataphatic, political methods of improvement of production do not provide the solution to the problem of the alienation of labor and have never succeeded to eliminate the latter, because their change did not happen on the organic, fundamental and inherent level of relations in the society. ${ }^{40}$ Yannaras points out that alienation and freedom of labor as such are complex non-objective issues, because labor moves constantly between alienation and authenticity. The reason for this indeterminate character is that the phenomenon of labor in itself does not represent a stable and objective state, but it is rather a changeable activity that can convert both in authenticity and in alienation, due to the fact that it is in itself a relation. Therefore, it is by all means possible to work in a non-alienated manner within the working surrounding determined by functionalism,

37 Cf. Yannaras, Orthos logos kai koinōnikē praktikē, p. 295 et seq.

38 Cf. Yannaras, Orthos logos kai koinōnikē praktikē, pp. 127-131.

39 Cf. Yannaras, Orthos logos kai koinōnikē praktikē, p. 303 et seq.

40 Cf. Yannaras, Orthos logos kai koinōnikē praktikē, pp. 299-301. 
utilitarianism or class differences. On that account, Yannaras concludes that, at the end, no change of objective production mechanisms can improve the alienation of labor and production, because neither alienation nor freedom depends in itself on objective conditions. For that reason, Yannaras refers first and foremost to the phenomenon of failed relationships towards material and societal surrounding as the fundamental cause of alienation. Only if they are improved i.e. if there is a demand for their change, this could overcome alienation, because it would form new needs, new demands and new collective "critical assessment" of the labor and production situation. ${ }^{41}$

Also in the apophatic perspective, the differences in capabilities and skills in the process of production are indispensable. A rejection of the difference, in the sense of an abstract equality, would not automatically contribute to the intended liberation and righteous relationships within the production process. Moreover, it is exactly this differentiation in expertise, capacities and responsibilities that could enable and liberate dynamics of relationships and could give proper impulses for the development of the collective production and in that sense to the prosperity of the autonomous entities. ${ }^{42}$

Correspondingly to the differences in capabilities, Yannaras indicates that the apophatic perspective neither absolutizes the private property nor tends to abolish it, but rather includes it in the dynamics of relations within society. The social question of private property, however ambiguous and multileveled it might be - wherefore, in the context of its thematization, Yannaras suggests a kind of "apophatic reservation" - could not be solved by applying extreme positions or in a manichaeistic manner, but only in the context of its functional deployment within the society and taking seriously the criterion of alienation. ${ }^{43}$ In other words, property should serve as material element for creative working processes and production as well as for the universal participation of workers, whereas the owner should consider his owner status a privilege and should handle (his) property with responsibility and in the sense of the common good. In that regard, the private property as well as production resources are not nationalized, but are intended to be put at the disposal of special interests and benefits of the community. The fact that someone is just a member of the autonomous entity should be reason enough to motivate him as a citizen to use the property and productive capacities in an appropriate way with the objective to invest primarily into the new quality of relations and consequently in the liberation of the subject. ${ }^{44}$

\footnotetext{
41 Cf. Yannaras, Orthos logos kai koinōnikē praktikē, pp. 296-299, 301-303.

42 Cf. Yannaras, Orthos logos kai koinōnikē praktikē, pp. 305-307.

43 Cf. Yannaras, Orthos logos kai koinōnikē praktikē, pp. 307-309.

44 Cf. Yannaras, Orthos logos kai koinōnikē praktikē, pp. 309-311.
} 
Nevertheless, in the apophatic perspective, any formal and external administrative control instance for estimating the level of the contribution of the owners to the community is not intended because that would limit the freedom. In this case, Yannaras suggests the common critical assessment i.e. the legal regulation of working relationships and deployment of resources for production. This would enable and guarantee to all the participants, i.e. not only to owners, the possibility of making elementary decisions on common issues. Yannaras believes that such a common practice i.e. the mutual dependence of owners and coworkers could create a common ground for the transformation of human relationships in the production as well as in the society. ${ }^{45}$

Acknowledgement of the Cataphatic Paradigm of Governance

In his criticism of the domination of rationality in political and social fields, Yannaras does not have a lopsided attitude. He also takes the role and impacts of the cataphatic paradigm seriously. The reason for that can surely be found in the essential role freedom plays for the apophatic stance, but also in the apophatic position that no approach or conception - even the apophatic one can have an a priori status. In that case, until the readiness of people is reached for the implementation of the apophatic paradigm of governance, some cataphatic solutions sustain societal dynamics and the pursuit of freedom as well as minimize alienation. ${ }^{46}$

One of these cataphatic solutions that tend to decrease alienation is the control of public offices. In the cataphatic conception, the latter can be put into practice by interventions of the central government or by relevant authorities. This control prevents the autonomization of institutions by connecting their work with actual tendencies in society and initiating reconstructions within them. Furthermore, the control can be exercised also by agents themselves (citizens, workers, members, stakeholders) - assisted by the central administration if there is such a need. ${ }^{47}$

In the apophatic perspective, however, the control of public offices and institutions should not come from any external factor, but it is principally the community which on the basis of concrete needs and based on the principle of the universal participation of the citizens should react in necessary cases. ${ }^{48}$ Yannaras mentions that the possibility of the communal control can be legally

\footnotetext{
45 Cf. Yannaras, Orthos logos kai koinōnikē praktikē, p. 311.

46 Cf. Yannaras, Orthos logos kai koinōnikē praktikē, pp. 292, 332.

47 Cf. Yannaras, Orthos logos kai koinōnikē praktikē, p. 324 et seq.

48 Cf. Yannaras, Orthos logos kai koinōnikē praktikē, p. 319 et seq.
} 
defined. ${ }^{49}$ As for the central government, its possible political interventionism, in the apophatic perspective, can be justified only by concrete needs and requests of the local community. ${ }^{50}$

Yannaras stresses that the bureaucracy is undeniably an accompanying phenomenon of the cataphatic political concepts. In fact, the bureaucratic system divides the central power into sectors of power, the bureaucracy positions itself between the government and people and consequently turns into an autonomized institution. In the situation of the alienation of the bureaucratic hierarchical authority from the "societal body", the citizen becomes deprived of his dignity often being victim of this impersonal mechanism. Yannaras mentions that the cataphatic approach tries to improve this alienation by radical decentralization of public offices and their control by the local self-administration. ${ }^{51}$

The apophatic perspective, however, will preserve institutions from becoming autarkic, and in that way from being alienated, by combining their work and their collectively produced outputs with relevant issues of the societal life, respecting thereby the criteria of creativity and acknowledgement of otherness. It will find solutions to the problems in an organic way i.e. the solutions should emanate from the culture of relationships and inter-subjective understanding of different needs and tendencies of individuals. ${ }^{52}$

According to Yannaras, one more indicator of alienation of the cataphatic concepts of governance is the "professional or commercial character" of politics. The notions "politician" and "citizen" nowadays designate two different functions, while in the Greek polis every citizen could get involved in the issues of the polis-community. In today's democratic system, however, citizens are excluded from taking part in direct decision making and in taking direct responsibility for the urban communities they live in. They cannot initiate by themselves spontaneous demands in their local community and have delegated these possibilities to the representatives, who handle them professionally as a part of their occupation. Yannaras strongly criticizes the party democracy as one of the alienated autonomized institutions and equals it to the "marketplace", which operates according to commercial laws and reduces the citizen to a passive "supporter" or "electing individual". ${ }^{3}$

49 Cf. Yannaras, Orthos logos kai koinōnikē praktikē, p. 311.

5o Cf. Yannaras, Orthos logos kai koinōnikē praktikē, p. 292 et seq.

$5^{1}$ Cf. Yannaras, Orthos logos kai koinōnikē praktikē, p. 325 et seq.

$5^{2}$ Cf. Yannaras, Orthos logos kai koinōnikē praktikē, pp. 322-324, 332.

53 Cf. Yannaras, Orthos logos kai koinōnikē praktikē, pp. 329-332. 


\section{Freedom and Failure of the Human Subject within the} Social Dynamics

The cataphatic logic produces political and societal models which tend to be rationally structured and efficient. On the other hand, the life of the human subject within this frame becomes alienated because the human subject has to adapt or even to subordinate to the rational schemes and principles planned in advance. This givenness leaves little or no opportunity to human subjects to develop their social goals spontaneously and freely i.e. to determine themselves, in accordance with their needs and within the social dynamics. Even though the modern critical thinking contributes to the revision of cataphatic aims and concepts and maintains dynamics of the societal event, it still produces new cataphatic paradigms, which only oppose the previous patterns and can adopt the same logic of domination so that they cannot bring about the liberation of the human subject. By virtue of the compelling character of logic, the rational cataphatic conceptions of governance do not tolerate mistakes, challenges or failures. If they occur, they are followed by corresponding sanctions from marginalization to elimination in the name of the people.

On the other hand, for the apophatic logic, the failure is the "touchstone" for realization of politics. In other words, the apophatic paradigm, in its core, tolerates differences, even stagnation, opposition as well as cataphatic logic, and enables the participants of the communal event, even by making mistakes, to develop readiness for the apophatic paradigm. The intention of the latter is not any prescribed program or objective ideal, neither that of common happiness, but merely the freedom of the human subject as well as dynamics of relations, which does not necessarily, but can potentially develop towards the existential and social maturity of acknowledgement of otherness and authentic human liberation. Yannaras stresses that this kind of political practice is probably not efficient and still utopia, but it is the expression of social maturity and, therefore, the only way of the authentic liberation and realization of the subject in the society, because the subject does not rely on the protective activity of any exterior factor. ${ }^{54}$

Consequently, freedom is for the apophatic perspective neither an objective good nor a value, both of which can be possessed and therefore used for purposes, but rather the existential level of the acknowledgment of the identity of the subject. The latter means that the subject should be acknowledged in the society and within its dynamic and de-objectified relations as the being, which

54 Cf. Yannaras, Orthos logos kai koinōnikē praktikē, pp. 313-320; Yannaras, The Freedom of Morality, pp. 204-211. 
it really is i.e. in his otherness. For the apophatic perception, however, this is not the only dimension of freedom. Furthermore, in the apophatic perspective, freedom has also its interior dimension: the struggle against passions and egoism of the human nature and liberation from them in order to prevent the individual to deteriorate the otherness of oneself and of the Other. Finally, the third dimension of freedom, Yannaras suggests, is the possibility to distance oneself from the apophatic logic and fall into the cataphatic thinking and practice, but also to find a way back to the apophatic paradigm. ${ }^{55}$

Therefore, the crucial point in the apophatic perspective is neither external change of conditions nor obedience to a logical conception or to any a priori authority, but the synergy of the inter-logical and the inter-subjective relations in the society, which on the basis of concrete necessities could lead to the formulation of a real demand for political and social change. As Yannaras states, people are generally not yet ready for such a radical transformation. The reasons for such an insufficient interest could be found in the fact that the confidence in cataphatic conceptions, their solutions, representatives and security they convey is still strong, so that the desire for fundamental reforms still fails to appear. Yannaras is optimistic and believes that one day the necessary preconditions for apophatically perceived decentralization and self-government in politics and production practice will be created, so that the institutions would possess the ability to manifest their societal functionality and politics would be exercised as an art. This new political culture would only be possible if maturity was reached to put the person, its otherness and its freedom in the center of the societal event and dynamics i.e. if the transition from the

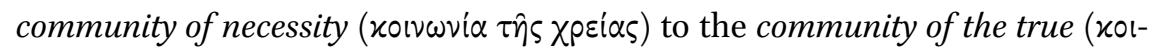
$\left.\nu \omega v^{\prime} \alpha \tau 0 \hat{\alpha} \dot{\alpha} \eta \theta_{0} \hat{\varsigma} \varsigma\right)$ occurs. Only in this way, the institutions which essentially impact human life would escape the alienation and could shape in a creative and meaningful way a society of relationships. In this context, the hierarchy and the control of the institutions exercised by the participants themselves becomes an act of responsibility, creativity and collaboration, so that every member of the community becomes an agent in the art of politics. ${ }^{56}$

\section{$9 \quad$ Conclusion}

The article shows that, in Yannaras's interpretation, there is an organic interrelation between the Greek polis, the (Early) Church communities and the local

\footnotetext{
55 Cf. Yannaras, Orthos logos kai koinōnikē praktikē, pp. 278-285.

56 Cf. Yannaras, Orthos logos kai koinōnikē praktikē, pp. 332-336; Yannaras, Kephalaia Politikēs Theologias, p. 42 et seq.
} 
autonomous entities (communal polities) that could be realized in the future. The connecting links of these concepts are apophatism and Yannaras's interpretation of Hellenism. ${ }^{57}$ Yannaras traces apophatism to the Greek antiquity and considers it a constituent of the living Greek philosophical and theological tradition beginning with Heraclitus (6th to $5^{\text {th }}$ BC) and reaching its peak with Gregory Palamas (14th century). ${ }^{58}$ According to Yannaras, this tradition continued to exist also after the Fall of Constantinople (1453), however, mostly in various other cultural forms (the Church, ethos, art, customs etc.). In order to depict the polis and ecclesiastical culture persisting also under the Ottoman rule, Yannaras uses the image of the feast, which incorporates community, participation, social event, truth, sense, personhood, otherness, freedom, love, Eros, trade, politics etc., and in that way serves as a cultural and existential paradigm of overcoming alienation and isolation. ${ }^{59}$ Yannaras combines the Greek apophatic and ontological philosophical and theological tradition, his interpretation of the polis and direct democracy as well as the above-mentioned existential experience of the Church life and confronts them with the modern issues of rationalism, criticism and alienation of the human subject. One of the results of this creative reasoning is the concept i.e. the vision of the autonomous political entities that was presented above.

This critical synthesis provokes, however, many questions. Only some of them can be mentioned here. The first question refers to the sustainability of these communities. It is not easy to answer it, because Yannaras's conception does not represent an elaborate plan which could be easily put into practice and verified. Although rationally and coherently explained, it is still a future vision. Therefore, in spite of the precise rational argumentation of the concept and the general possibility to be analyzed by political sciences, economy, sociology and philosophy, its examination would ultimately result in hypotheses and prognoses.

One of the important achievements of modern democracy is the protection of individual freedom vis-à-vis the state. In the past, the individual was very often undefended and remained at the mercy of different state and political structures. This is a right that could be accepted also by the apophatic perspective, because this form of protection need not differ from the concept of the otherness, and the protection of individual freedom, and privacy does not necessarily mean separation from the community.

\footnotetext{
57 Cf. Yannaras, Kephalaia Politikēs Theologias, p. 20 et seq.

$5^{8}$ Cf. Yannaras, On the Absence and Unknowability of God, p. 117; Yannaras, Christos: Orthodoxy and the West, p. 66 et seq.

59 Cf. Yannaras, The Freedom of Morality, pp. 219-223; Yannaras, Kephalaia Politikēs Theologias, p. 62 et seq.
} 
Also, how would the autonomous entities react to the challenges of local, regional and global crises and catastrophes that would go beyond their relatively small extent and capacities? In this case, it would be necessary to define more precisely the role of the central government, which Yannaras does not neglect, as well as the modes of cooperation and institutional structures at a regional and international level. The latter is based on the fact of increasing interdependence in a globalized world, but also on the attitude that an autonomous entity, which would be self-sufficient, would contradict the principles of relation and otherness. Moreover, the freedom of one autonomous entity would also include the freedom of all other communities. However, any supraentity should be put in service of the local communities.

Even though Yannaras criticizes nationalism, ${ }^{60}$ his concept of the selfgoverning entities does not automatically lead to the abolition of the nationstate, because he does not precisely define to which central government he refers to (regional, national, supra-national). He only generally characterizes the relation between the central government and the autonomous local communities. ${ }^{61}$

Furthermore, the following question can be raised: How would the autonomous entity react to the phenomena of pluralism at the internal as well as the external level? Would such a relatively small communal entity be able to accept as equal members also those whose cultural, religious, ideological, social and other characteristics essentially differ from its own collective identity? Could, therefore, the autonomous local community become the place of hospitality where those who are different could be acknowledged by their name?

Due to the fact that Yannaras also criticizes the globalizing processes, which are only based on material values and utilitarianism, ${ }^{62}$ it is hard to believe that he could imagine his concept of the autonomous entities in such a context. That would only be possible if the globalization processes allowed the entities' self-determination in its broad sense and absolute cultural autonomy.

\section{Biography}

Miroljub Gligoric is an Orthodox theologian born in 1976 in Serbia. He studied Orthodox and Catholic theologies in Belgrade, Regensburg and Vienna

6o Cf. Yannaras, Against Religion, p. 162.

61 Cf. Yannaras, Orthos logos kai koinōnikē praktikē, pp. 291-293.

62 Cf. Yannaras, Kephalaia Politikēs Theologias, p. 85 et seq. 
and holds a doctorate in theology from the University of Vienna. He teaches Orthodox Theology at institutions of higher education.

\section{Bibliography}

Gligorić, Miroljub: Person-Logos-Sein. Eine Darstellung der ontologischen und erkenntnistheoretischen Begriffe im Denken von Christos Yannaras. Freiburg/Basel/ Wien: Herder 2020.

Mitralexis, Sotiris: On the early development of Christos Yannaras's political theology, in: Andreas Andreopoulos/Demetrios Harper (eds.): Christos Yannaras. Philosophy, Theology, Culture. London/New York: Routledge 2019, pp. 105-124.

Petrà, Basilios: Christos Yannaras. The Apophatic Horizon of Ontology. Cambridge: James Clark \& Co 2019.

Skliris, Dionysios: Christos Yannaras' Political Ontology. An Introductory Sketch, in: Mitralexis, Sotiris (ed.): Polis, Ontology, Ecclesial Event. Engaging with Christos Yannaras' Thought. Cambridge: James Clarke \& Co 2018, pp. 19-46.

Yannaras, Christos: Kephalaia Politikēs Theologias. Athens: Papazēsē 1976 [Гıаvvapâ,

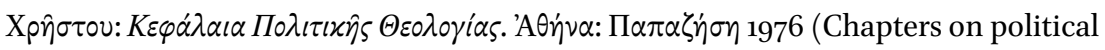
theology)].

Yannaras, Christos: The Freedom of Morality. Crestwood (NY): St. Vladimir's Seminary Press 1984 .

Yannaras, Christos: He hapologêtikē sta horia tēs orthodoxou theologias [Apologetics in the context of Orthodox theology]. Athens: Grēgorē ${ }^{21989}$, in: Basilio Petrà (ed.): Christos Yannaras. The Apophatic Horizon of Ontology. Cambridge: James Clark \& Co 2019 .

Yannaras, Christos: To pragmatiko kai to phantasiōdes stēn politikē oikonomia. Athens:

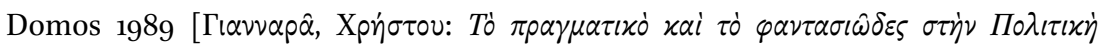

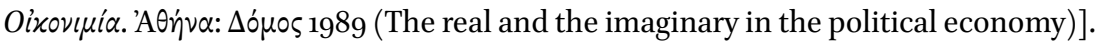
Yannaras, Christos: Elements of Faith. Edinburgh: T\&T Clark 1991.

Yannaras, Christos: On the Absence and Unknowability of God. Heidegger and the Areopagite. London/New York: T\&T Clark 2005.

Yannaras, Christos: Orthodoxy and the West. Hellenic Self-Identity in the Modern Age. Brookline, MA: Holy Cross Orthodox Press 2006.

Yannaras, Christos: Orthos logos kai koinōnikēpraktikē. Athens: Domos ${ }^{4} 2006$ [Гıаvvapâ,

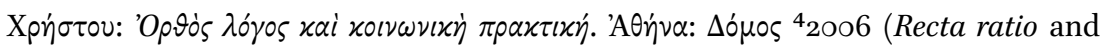
Social Practice)].

Yannaras, Christos: A Note on Political Theology, in: Fr. Gregory Edwards/Herman A. Middleton (eds.): The Meaning of Reality. Essays on Existence and Communion, Eros and History. Los Angeles: Sebastian Press \& Indiktos 2011, pp. 149-152. 
Yannaras, Christos: Hexi philosophikes zōgrafies „ekomisa eis tēn technēn“ Athens: Ikaros

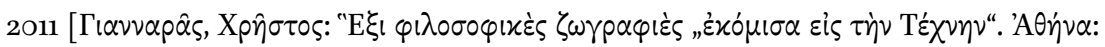
"Ixapos 2011 (Six philosophical sketches "I have brought to art")].

Yannaras, Christos: Relational Ontology. Brookline, MA: Holy Cross Orthodox Press 2011.

Yannaras, Christos: Against Religion. The Alienation of the Ecclesial Event. Brookline, MA: Holy Cross Orthodox Press 2013.

Yannaras, Christos: Person and Eros. Brookline, MA: Holy Cross Orthodox Press 2015.

Yannaras, Christos: The Schism in Philosophy. The Hellenic Perspective and its Western Reversal. Brookline, MA: Holy Cross Orthodox Press 2015.

Zizioulas, John D.: Being as Communion. Studies in Personhood and the Church. Crestwood, NY: St Vladimir's Seminary Press 1985. 